\title{
RECORDS OF THE PARULA WARBLER IN ALBERTA AND SASKATCHEWAN
}

by Spencer G. Sealy, Museum of Zoology, University of Michigan, Ann Arbor, Michigan

The Parula Warbler (Parula americana) was added unequivocally to the check-list of Saskatchewan birds when an adult male was found by E. Manley Callin on the grounds of the Fort Qu'Appelle Sanatorium and photographed the next day by Fred W. Lahrman (Callin, 1956). The bird remained on these premises for eight days, from May 31 to June 8. An earlier sight record of a male at Emma Lake on June 27, 1939, by Farley Mowat and A. W. Frank Banfield was not published by Mowat (1947), apparently because the species had not been recorded previously in the province (Houston, 1958a). The province's third Parula Warbler record was obtained at the summer meeting of the Saskatchewan Natural History Society in Moose Mountain Provincial Park on June 14, 1959; here, not only was the adult male observed by many people attending the meeting but its song was also recorded (Gunn, 1959).

A fourth record of this species was obtained on October 21, 1965, when Mrs. Betty Binnie spotted a single Parula Warbler on the grounds of the Provincial Correctional Institute just east of Regina (Binnie, 1965). This bird was seen again by Mrs. Binnie on October 22 and on October 23 was observed by Regina birdwatchers, Margaret Belcher and the late Dr. Lucy Murray. The bird was last seen on the morning of October 24 when Robert W. Nero confirmed the identification.

The only Alberta record of this species is a specimen taken by $D$. A. Boag at the Alberta Biological Station, 20 miles west of Turner Valley, on June 6,1958 . The bird was an adult male (Boag, 1958). There are no records in Manitoba west of the southeastern corner of this province where Parula Warblers normally breed (Godfrey, 1966).

At noon on June 6, 1957, I observed a male Parula Warbler at about 15 feet in Kindersley, Saskatchewan. The bird was observed for about 20 minutes as it moved among the branches of a poplar tree in the centre of the town. The identification was confirmed from Pearson (1936: plate 94) immediately after the observation was made. There was no doubt in my mind at the time that the bird was of this species.

The A.O.U. Check-List (1957:486) considered the Parula Warbler to be "casual to southern Saskatchewan (Sovereign)"; Godfrey (1966:325) cited this record and presented another one from McLean. Houston (1958b: 45) traced these records to the files of the United States Fish and Wildlife Service and was provided with details of them by Chandler S. Robbins (personal correspondence to Houston, January 16, 1958): "One seen at Bonniebrae, McLean, Saskatchewan, on May 10, 1935. Rare. One seen at Sovereign, June 5, 1930, by Beryl M. Dickson." As pointed out by Houston, these records are considered hypothetical. I contacted Robbins to obtain the sex of the birds involved in these observations and he stated (personal correspondence, October 7, 1970) that "the original records provide no further information than what we provided $\mathrm{Dr}$. Houston."

Griscom and Sprunt (1957:98) give the normal breeding range of the Parula Warbler as extending "from southeastern Manitoba, central Ontario, southern Quebec, Maine, Prince Edward Island, south to eastern Texas, Louisiana, Mississippi, Alabama and central Florida." The status of the Parula in Alberta has to be designated as "accidental" (see Grinnell, 1922) on the basis of its single recorded occurrence in that province. Its status in Saskatchewan, however, is somewhat different. From 1930 to the present date (a span of 40 years) seven 
Parula Warblers have been reported; thus, we have a mean of one observation every 5.9 years. This confers the status of "irregular visitant" (see Belcher, 1961:14) on the Parula in Saskatchewan.

Provided that the occurrence of Parulas in Saskatchewan has not coincided with the increase in the number of bird-watchers in the province, the possibility exists that it is expanding its breeding range. Griscom and Sprunt (1957:97) have pointed out that northern populations of this species "rarely nest anywhere except where the tree lichen, Usnea, occurs"; as Binnie (1965) stated, this lichen is prevalent throughout the northern coniferous forests of Saskatchewan. Thus, nestsites would be available for this species in Saskatchewan provided that its other ecological requirements could be met.

It is interesting to note that all of the Parula records, except Binnie's sighting at Regina in October, were made in May and June; all of the birds whose sex was determined by the observer were males. Also, all of these records, except possibly the Alberta specimen and Emma Lake bird, were ecologically misplaced and have little immediate zoogeographical significance, since the birds were widely displaced from their typical habitat and probably had little if any chance of becoming established, even if females had been available. However, their importance may lie in the fact that they were possibly en route to suitable habitat in the coniferous forest where they might constitute a pioneering nucleus. Since no females have been observed (possibly because they do not sing and lack conspicuous coloration) in company with any of these males, it appears that these males were strictly irregular visitants and probably did not nest in Saskatchewan. However, such irregular visitants may indicate that the species is healthy and can afford to wager such high-risk pioneers; but, the success of such pioneering usually depends upon the numbers of individuals involved, the chances of an individual settler being very slim.
That the Parula Warbler is capable of locating suitable habitat and suc. cessfully raising young far away from its normal breeding range is demonstrated by its occurrence (Gould, 1957) and nesting (Williams, et al, 1958) in California. The latter authors observed at least three individuals in Point Lobos Reserve State Park, California, and just outside the park's eastern boundary almost daily from May 18 to July 16, 1952. Two nests were found, both situated in the tree lichen (Romalina reticulata), and it was ascertained that at least one young fledged from one nest and two from the other.

An extension of the breeding range of another wood warbler, the Goldenwinged Warbler (Vermivora chrysoptera), in Ontario has been documented recently (Godfrey, 1969). This is a northeastern American species whose range also extends into the southeastern corner of Manitoba (A.O.U., 1957), and just recently this species was recorded in Saskatchewan (Brazier, 1962; Bard, 1968). Other warblers with northeastern American breeding ranges which also have been recorded recently in Saskatchewan are the Prothonotary Warbler (Protonotaria citrea) (Bobbitt, 1969) and Bluewinged Warbler (V. pinus) (Brazier, 1966). Thus, close scrutiny of warblers in Saskatchewan will possibly continue to turn up these eastern warbler species, and will sometime provide this province with its first breeding record of the Parula Warbler.

\section{LITERATURE CITED}

American Ornithologists' Union. 1957. Checklist of North American birds. Fifth edition. Lord Baltimore Press, Baltimore. $691 \mathrm{pp}$.

Bard, F. G. 1968. Taping the song of the Golden-winged Warbler. Blue Jay, $26: 177$ 178.

Belcher, M. 1961. Birds of Regina. Sask. Nat. Hist. Soc., Spec. Publ. no. 3, 76 pp.

Binnie, A. 1965. Parula Warbler recorded near Regina. Blue Jay, $23: 170$.

Boag, D. A. 1958. Parula Warbler and Indigo Bunting in southwestern Alberta. Can. Field Nat. 72:173-174.

Bobbitt, D. G. 1969. Sighting of a Prothonotary Warbler in Regina. Blue Jay, $27: 149$.

Brazier, F. 1962. A Golden-winged Warbler in Regina. Blue Jay, $22: 153-154$.

Brazier, F. 1966. Saskatchewan's first specimen of the Blue winged Warbler. Blue Jay, $24: 9-10$.

Callin, E. M. 1956. Saskatchewan's first Parula Warbler. Blue Jay, $14: 90-91$.

Godfrey, W. E. 1966. Birds of Canada. Nat. 
Mus. Canada Bull. no. 203. Biol. Ser. no. 73. Queen's Printer, Ottawa. 428 pp.

Godrey, W. E. 1969. The Golden-winged Warbler in Muskoka County, Ontario. Can. Field-Nat., $83: 281$.

Grinnell. J. 1922. The role of the "accidental." Auk, $39: 373-380$.

Griscom, L., and A. Sprunt, Jr. 1957. The warblers of America. Devin-Adair, New York. $356 \mathrm{pp}$.

Gould, F. J. 1957. Specimen of Parula Warbler from southern California. Condor, 59:210.

Gunn, W. W. H. 1959. Song of Parula Warbler (Parula americana) recorded at Moose Mountain Provincial Park. Blue Jay, 17 :114115 .
Houston, C. S. 1958a. Record of Parula Warbler at Emma Lake, June, 1939. Blue Jay, $16: 158$.

Houston, C. S. 1958b. An evaluation of the distribution records for Saskatchewan birds in the revised edition of the A.O.U. Checklist. Blue Jay, $16: 44-47$.

Mowat, F. W. 1947. Notes on the birds of Emma Lake, Saskatchewan. Can. Field-Nat., $61: 105-115$.

Pearson, T. G. 1936. Birds of America. Doubleday and Company, Inc. 289 pp.

Williams, L., K. Legg, and F. S. L. Williamson. 1958. Breeding of the Parula Warbler at Point Lobos, California. Condor, 60 :345354.

\title{
FIRST SIGHT RECORD OF THE BAND-TAILED PIGEON IN SASKATCHEWAN
}

\author{
by Wayne Renaud, Box 327, Rosetown
}

On August 6, 1970, at 8:00 a.m. my brother Don glimpsed a strange pigeon as it flushed with a flappy flight from our bird bath near our house in Valley Centre, 18 miles north and seven miles east of Rosetown, Saskatchewan. The bird flew north and alighted in a maple in the neighbouring yard and, although the bird had perched in the green foliage, the head, neck and back were visible. Don immediately obtained $7 \times 50$ binoculars and observed the bird from as close as 40 feet in bright, hazy sunlight. The white nape crescent was clearly seen for the pigeon had its back to the observer and light was shining directly on the bird.

The pigeon was then frightened to a grove of poplars about 400 yards to the west where it perched at a height of about 40 feet among dead poplar branches. Again the observer was able to approach to within 60 yards and he noted the dark primaries, the lighter grey back and the dark median line on the square tail. The pigeon was observed intermittently for about $15 \mathrm{~min}$ utes before the observer left the area.

No further attempt was made to study the bird until that evening when I took binoculars and searched the trees in Valley Centre. The bird was finally located at $7: 40$ p.m. as it perched on a dead poplar branch in a grove of poplars and maples by a farm at the north end of town. Here I was able to approach to within 50 yards of the bird, and the neck crescent, square, banded tail and general stocky, pigeonlike appearance were clearly evident. I studied the bird for 10 minutes; then I left and returned at 8:20 with my brother. By then, the bird had moved to the top of another dying poplar a few dozen yards away from its previous perch and appeared to be resting for the night. Again we approached the bird, this time no closer than within 65 yards. While we watched, a pair of Mourning Doves (Zenaidura macroura) came to perch in the same tree as the pigeon; by comparison the pigeon was about twice as broad and slightly longer. The bird was on the same branch when we departed at 8:40.

Although I searched the area thoroughly the following day I could not relocate the pigeon.

All the field marks point to its being a Band-tailed Pigeon (Columba fasciata), a species not previously recorded in Saskatchewan. Godfrey (Birds of Canada, 1966, p. 206) gives the range of this species as "southwestern British Columbia", thus placing this record some 600 miles out of its normal range. Bent (U.S. Natl. Mus. Bulletin \#162) states that "Band-tailed Pigeons are rarely taken outside of their range" and indeed there appear to be only two other Canadian records, both from Alberta, one a specimen secured July 27, 1967 at Leduc, and the other a sight record of a bird observed August 16, 1968 west of Calgary (See Blue Jay, 26:181, December, 1968). 